\title{
Seasonal variation of the essential oil from two Brazilian native Aldama La Llave (Asteraceae) species
}

TUANE S. DE OLIVEIRA ${ }^{1}$, ALINE B. BOMBO ${ }^{1,2}$, ADRIANA S.S. DE OLIVEIRA ${ }^{3}$,
VERA L. GARCIA ${ }^{3}$ and BEATRIZ APPEZZATO-DA-GLÓRIA ${ }^{1}$

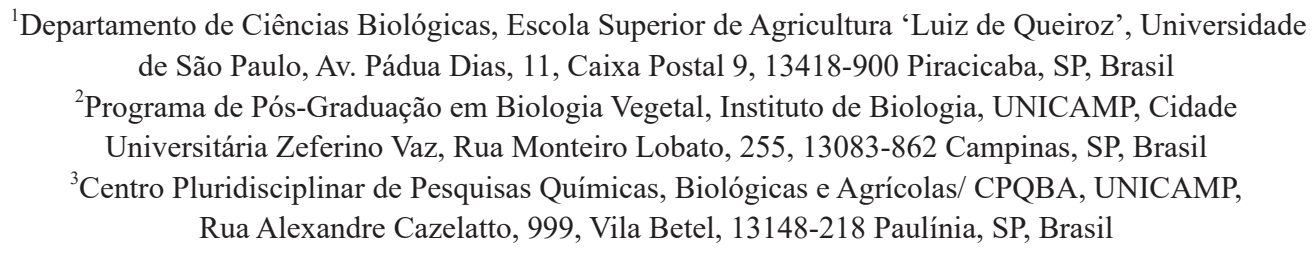

Manuscript received on October 1, 2015; accepted for publication on March 1, 2016

\begin{abstract}
Aldama arenaria and A. robusta are morphologically similar aromatic species that have seasonal development. The yield and chemical composition of essential oils from aerial and underground vegetative organs of these species were compared to verify the production of volatile metabolites in flowering and dormant phases of development and to identify if there are unique compounds for either species. The major compound in the essential oils from A. arenaria leaves was palustrol (16.22\%) and for aerial stems was limonene (15.3\%), whereas limonene (11.16\%) and $\alpha$-pinene $(19.64 \%)$ were the major compounds for leaves and aerial stems from $A$. robusta, respectively. The major compound for the underground organs was $\alpha$-pinene, in both species and phenological stages. High amounts of diterpenes were found especially for A. arenaria essential oils. Each analyzed species presented unique compounds, which can provide a characteristic chemical profile for both species helping to solve their taxonomic problems. This study characterized for the first time the yield and essential oil composition of A. arenaria and A. robusta, which have medicinal potential, and some of the compounds in their essential oils are unique to each one and may be useful in helping the correct identification of them.
\end{abstract}

Key words: Aldama arenaria, Aldama robusta, Viguiera, phenological phases, terpenes, vegetative organs.

\section{INTRODUCTION}

Aldama arenaria (Baker) E.E.Schill. \& Panero (=Viguiera arenaria Baker in Martius) and $A$. robusta (Gardner) E.E.Schill. \& Panero (=Viguiera robusta Gardner in Hook) are herbs and subshrubs with a thickened underground stem and seasonal development (Magenta et al. 2010). During

Correspondence to: Beatriz Appezzato-da-Glória

E-mail: bagloria@usp.br favorable periods of development, these species emit shoots from the underground system and produce flowers. In cold and dry periods, these species lose their shoots and survive only via underground organs, which characterize the dormant period. Both species are strongly aromatic due to the production of essential oils (EOs).

Essential oils are generally odoriferous, liquid (Bakkali et al. 2008, Simões and Spitzer 2004), complex mixtures of lipophilic substances that 
primarily consist of low molecular weight volatile terpenes (Fahn 1979, 2000). In general, these compounds play important ecological roles in plants (Harborne and Turner 1984), such as protecting against microorganisms and herbivores, attracting pollinators, and acting as allelochemicals (Ryan 2001, Wink 2009, Arimura et al. 2010, Chauveau et al. 2011). Thus, the biosynthesis, composition, and yield of EOs may be influenced by biotic or abiotic environmental factors (Marotti et al. 1996, Sangwan et al. 2001, Deschamps et al. 2008). In this context, the chemical composition and yield of EOs may differ between organs from the same plant and between different phenological phases of a plant's development (Deschamps et al. 2008, Murari et al. 2008).

Although environmental factors may influence the chemical composition and yield of EOs, some compounds are characteristic of certain plant groups and may thus be used in chemotaxonomy (Gören et al. 2002, Croteau et al. 2005). For example, some monoterpenes, such as $\alpha$-pinene and $\beta$-pinene, are common among angiosperms, and quantitative variations in these compounds may be a diagnostic feature for distinguishing between species (Harborne and Turner 1984). The species Aldama arenaria and A. robusta belong to Asteraceae family (Magenta and Pirani 2014) and are easily confused in herbalized materials, being only distinguished based on pollen features (Magenta 2006). Data on the chemical composition of EOs from these species could help distinguish between both of them. In a study comparing the chemical composition of secretions from glandular trichomes of Aldama robusta, Da Costa et al. (2001) rated it as a "chemo consistent" taxon, with a similar chemical pattern between different populations.

Additionally, phytochemical studies have demonstrated the biological activity of root compounds from Aldama arenaria (Tirapelli et al. 2002, Ambrosio et al. 2008, Hipolito et al. 2009,
Porto et al. 2009) and A. robusta (Tirapelli et al. 2002, Valerio et al. 2007).

For these reasons, the purpose of the present study was to characterize and compare the yield and chemical composition of EOs from the vegetative organs of Aldama arenaria and A. robusta, to verify if there is any difference in the production of volatile metabolites during flowering and dormant periods, and to determine whether either species produces unique compounds that may be useful as distinguishing features.

\section{MATERIALS AND METHODS}

\section{BOTANICAL MATERIAL}

Samples were collected from vegetative organs of Aldama arenaria (Baker) E.E.Schill. \& Panero and A. robusta (Gardner) E.E.Schill. \& Panero in the flowering stage (leaf, aerial stem, xylopodium, and root) and dormant stage (xylopodium and root). At least four individuals for each species and developmental stage were sampled. Samples from $A$. arenaria were collected at the Itirapina Ecological Station (22 ${ }^{\circ} 14^{\prime}$ S and $\left.47^{\circ} 51^{\prime} \mathrm{W}\right)$, and samples from A. robusta were collected at the Mogi Guaçu Biological Reserve (Campininha Farm) (22 $42^{\circ}$ 'S and $47^{\circ} 37^{\prime} \mathrm{W}$ ), both located in São Paulo, Brazil. The species were identified by Mara Angelina Galvão Magenta and the material was registered and incorporated into the herbarium collection (ESA) of the Escola Superior de Agricultura "Luiz de Queiroz", at the University of São Paulo, under the numbers 111847 and 114255 , respectively.

\section{OBTAINING THE ESSENTIAL OILS}

Samples of fresh leaves, aerial stems, xylopodia, and roots from different individuals were pooled and submitted separately to the essential oils extraction by hydrodistillation method in a Clevenger system, for three hours. The essential oils were separated and stored at low temperatures, and the yields were calculated based on the fresh plant material. 


\section{ANALYSIS OF ESSENTIAL OILS}

Samples of essential oils were analysed by gas chromatography coupled with flame ionization detector (GC-FID) and gas chromatography coupled with mass spectrometry (GC-MS). All the samples were prepared in ethyl acetate at a concentration of $20 \mathrm{mg} \cdot \mathrm{mL}^{-1}$.

The GC-FID analyses were done using a Thermo Mod. Serie Trace CG-ULTRA, which was equipped with a flame ionization detector (FID); AS 3000 auto-sampler, a split/splitless injector, and an HP-5 (25 m x $0.20 \mathrm{~mm} \times 0.33 \mu \mathrm{m})$ capillary column. The temperatures were used: injector $=$ $220{ }^{\circ} \mathrm{C}$; detector $=280{ }^{\circ} \mathrm{C}$; and column $=60{ }^{\circ} \mathrm{C}$, raised at $3^{\circ} \mathrm{C} \cdot \mathrm{min}^{-1}$ to $240{ }^{\circ} \mathrm{C}$ (held for $7 \mathrm{~min}$ at this temperature); the flow rate of carrier gas (super-dry $\mathrm{He})=1.0 \mathrm{~mL} \cdot \mathrm{min}^{-1}$.

The GC/MS analysis were carried out in a HP 5890 series II chromatograph (Hewlett-Packard, Palo Alto, CA, USA) with Hewlett-Packard 5971 mass-selective detector, split/splitless injector, and HP-5 capillary column ( $25 \mathrm{~m} \times 0.20 \mathrm{~mm} \times 0.33$ $\mathrm{mm})$. The-temperatures were: injector $=220{ }^{\circ} \mathrm{C}$; detector $=280{ }^{\circ} \mathrm{C}$; and column $=60{ }^{\circ} \mathrm{C}$, raised at $3{ }^{\circ} \mathrm{C} \cdot \mathrm{min}^{-1}$ to $240{ }^{\circ} \mathrm{C}$ (held for $7 \mathrm{~min}$ at this temperature); the flow rate of carrier gas (super-dry $\mathrm{He})=1.0 \mathrm{~mL} \cdot \mathrm{min}^{-1}$.

The chemical composition was determined based on retention time data obtained from GCFID, and based on mass spectra obtained from GC-MS, and comparison of the mass spectra with data from the NIST 11 Mass Spectral Library (Fabrication Varian Inc.). Arithmetic indexes (IA's) were calculated using Van den Dool Kratz equation and co-injection patterns for hydrocarbons and the data described by Adams (2007).

\section{RESULTS}

YIELD OF ESSENTIAL OILS

There were differences in the yield of EOs obtained from the vegetative organs of Aldama arenaria and
A. robusta (Tables I, II and Fig. 1). The highest yield of EOs in Aldama arenaria in the flowering stage was obtained from the leaves $(0.23 \%)$, followed by roots $(0.19 \%)$ and xylopodium $(0.07 \%)$ (Table I). In the dormant stage, the level of EOs from the xylopodium increased by $100 \%$ relative to the flowering stage, whereas EOs from the roots increased by $73 \%$.

In $A$. robusta, in the flowering phase, the highest yield of EOs was obtained from the roots $(0.32 \%)$, followed by the leaves $(0.21 \%)$, and xylopodium $(0.08 \%)$ (Table II). In the dormant stage, the level of EOs from the xylopodium increased by $62 \%$ relative to the flowering stage, while the level of EOs from the roots did not change.

\section{CHEMICAL COMPOSITION OF ESSENTIAL OILS}

In addition to changes in yield, there were also differences in chemical composition for EOs from the vegetative organs in the flowering (leaf, stem, root, and xylopodium) and in the dormant stage (root and xylopodium) in both species (Table I and II). Monoterpenes represent the major compounds identified of EOs obtained from roots and xylopodia, in both flowering and dormant stages, with predominance of $\alpha$-pinene. The sesquiterpenes content was similar for both species and stages. Cyperene was the predominant compound in the roots of both species. The majority identified compounds of xylopodia was carotol in A. arenaria and germacrene $\mathrm{D}$ in $A$. robusta. Diterpene content was higher to the flowering stage of A arenaria, in both subterranean organs. In dormant stage, the monoterpene content in the EO from xylopodia and roots increased, while the sesquiterpene and diterpene contents decreased. The identification of diterpenes was performed by comparative analysis of their mass spectra with literature data (Adams 2007) (Mass Spectra of Diterpenes - Supplementary Material).

Concerning the essential oils from the aerial organs, the EOs from leaves were primarily made 


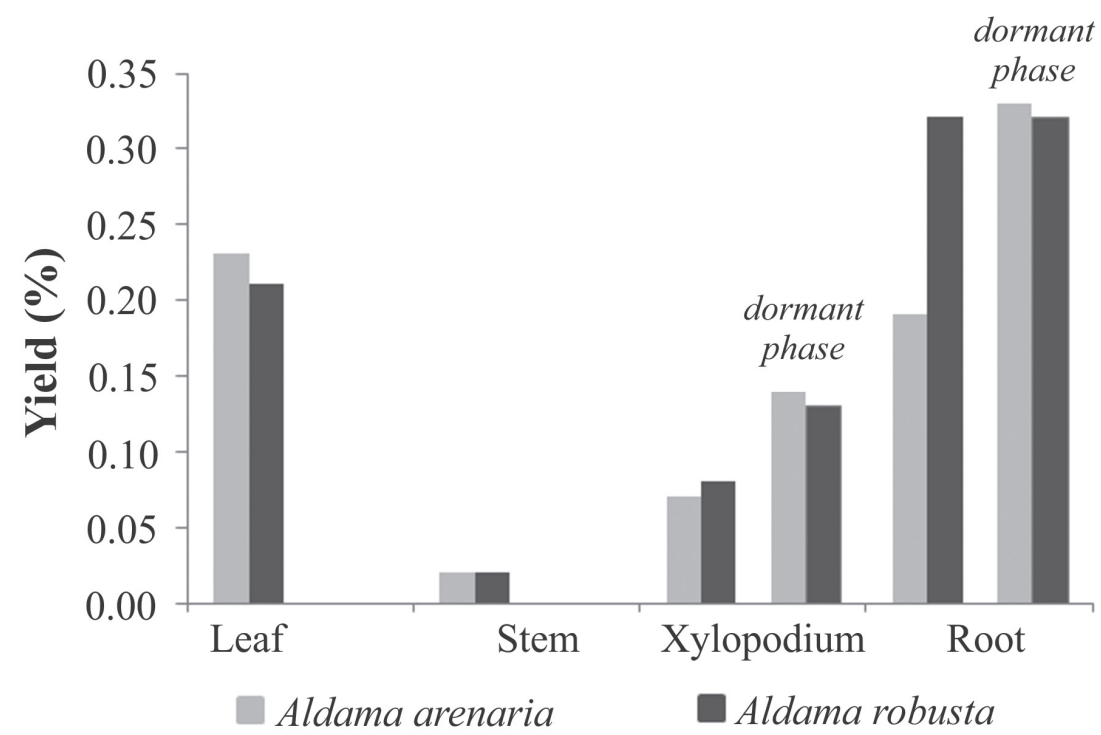

Figure 1 - Comparison of the essential oils yield ( $\% \mathrm{w} / \mathrm{w})$ from vegetative organs of Aldama arenaria and A. robusta, obtained from leaves, stems, xylopodia, and roots.

up of sesquiterpenes (52.31\%), whereas the EOs from stems presented similar proportion of mono and sesquiterpenes $(24.42 \%$ and $18.93 \%)$ followed lower diterpene content (10.33\%). For A. robusta the EOs from leaves showed higher monoterpenes content (47.83\%), followed by sesquiterpenes (32.31\%) and low concentrations of diterpenes $(1.49 \%)$, whereas the OEs from stems showed higher content monoterpenes $(67.82 \%)$, followed by sesquiterpenes $(16.84 \%)$ and diterpenes $(3.53 \%)$.

There were identified 14 exclusive compounds for Aldama arenaria and 10 exclusive compounds for $A$. robusta. For the first species, these compounds were sesquiterpenes and diterpenes and for $A$. robusta, they included mono, sesqui and diterpenes. The exclusive compounds are highlighted in Tables I and II.

TABLE I

Relative percentage of identified compounds of EOs from the vegetative organs of Aldama arenaria (Baker) E.E.Schill. \& Panero in the flowering (leaf, stem, root, and xylopodium) and dormant (root and xylopodium) stages. AI = Arithmetic Index, $n c=$ not calculated, $t=$ traces, $n d=$ not determined. Exclusive compounds are highlighted in the table.

\begin{tabular}{|c|c|c|c|c|c|c|c|}
\hline \multicolumn{4}{|c|}{ Phenological phase } & \multicolumn{2}{|c|}{ Flowering } & \multicolumn{2}{|c|}{ Dormant } \\
\hline & & Leaf & Stem & Xylopodium & Root & Xylopodium & Root \\
\hline \multicolumn{2}{|c|}{ Yield $(\% \mathrm{~m} / \mathrm{m})$} & 0.23 & 0.02 & 0.07 & 0.19 & 0.14 & 0.33 \\
\hline Compound & $\mathbf{A} \mathbf{I}_{\text {(calculated) }}$ & \multicolumn{6}{|c|}{ Relative area $(\%)$} \\
\hline$\alpha$-pinene & 933 & 1.14 & 4.05 & 31.44 & 40.72 & 45.47 & 40.35 \\
\hline Camphene & 948 & 0.20 & 0.15 & 0.45 & 1.39 & 1.56 & 1.74 \\
\hline$\beta$-pinene & 977 & 1.26 & 2.21 & 4.15 & 5.16 & 7.85 & 8.05 \\
\hline$\beta$-myrcene & 991 & 1.41 & 2.43 & 0.33 & 0.59 & 0.64 & 2.29 \\
\hline$\delta$-3-carene & 1011 & $\mathrm{t}$ & 0.28 & 0.86 & 5.17 & 3.82 & 13.58 \\
\hline Limonene & 1028 & 5.18 & 15.30 & 2.45 & 2.46 & 2.94 & 5.19 \\
\hline \multicolumn{2}{|c|}{ MONOTERPENES } & 9.20 & 24.42 & 39.68 & 55.49 & 62.28 & 71.2 \\
\hline Cyperene & 1395 & $\mathrm{t}$ & 0.37 & 3.22 & 9.50 & 2.10 & 7.45 \\
\hline E-caryophyllene & 1415 & 3.02 & 0.53 & $\mathrm{t}$ & $\mathrm{t}$ & nd & nd \\
\hline
\end{tabular}


TABLE I (continuation)

\begin{tabular}{|c|c|c|c|c|c|c|c|}
\hline \multicolumn{4}{|c|}{ Phenological phase } & \multicolumn{2}{|c|}{ Flowering } & \multicolumn{2}{|c|}{ Dormant } \\
\hline$\alpha$-santalene & 1417 & 2.10 & 0.94 & nd & nd & nd & nd \\
\hline$\alpha$-guaiene & 1435 & nd & nd & nd & nd & 1.34 & nd \\
\hline$\alpha$-humulene & 1450 & 2.19 & $\mathbf{t}$ & nd & nd & nd & nd \\
\hline$\gamma$-muurolene & 1477 & 4.38 & 0.88 & 0.95 & 0.53 & 4.53 & 2.56 \\
\hline Bicyclogermacrene & 1495 & 2.38 & $\mathrm{t}$ & $\mathrm{t}$ & $\mathrm{t}$ & nd & nd \\
\hline$\gamma$-cadinene & 1513 & 2.32 & $\mathbf{t}$ & t & $\mathbf{t}$ & $\mathbf{t}$ & $\mathbf{t}$ \\
\hline$\delta$-cadinene & 1520 & 2.91 & 2.52 & 2.81 & 1.78 & 2.04 & 1.30 \\
\hline Palustrol & 1564 & 16.22 & 3.32 & $\mathbf{t}$ & $\mathbf{t}$ & $\mathbf{t}$ & $\mathbf{t}$ \\
\hline Spathulenol & 1573 & 4.52 & 2.26 & $\mathrm{t}$ & $\mathrm{t}$ & $\mathrm{t}$ & $\mathrm{t}$ \\
\hline Caryophyllene oxide & 1579 & 2.39 & 0.70 & nd & nd & nd & nd \\
\hline Carotol & 1593 & 2.80 & 5.49 & 11.79 & 11.74 & 5.14 & 7.46 \\
\hline Ledol & 1598 & 3.79 & 1.01 & nd & nd & nd & nd \\
\hline $\begin{array}{c}\text { Muurola-4,10-(14)-dien-1- } \\
\text { 1 } \beta-01\end{array}$ & 1626 & 3.29 & 0.91 & 0.84 & $\mathbf{t}$ & nd & nd \\
\hline SESQUITERPEN & & 52.31 & 18.93 & 19.91 & 23.55 & 15.15 & 18.77 \\
\hline Pimara-8(14),15-diene & 1940 & $\mathbf{t}$ & 1.76 & 6.55 & 5.08 & 4.0 & 1.08 \\
\hline 8及-podocarpan-8-ol & nc & nd & 1.11 & 3.37 & 1.51 & nd & nd \\
\hline Pimaral & nc & nd & 2.01 & 5.08 & 2.08 & 1.90 & 0.55 \\
\hline Ent-8(14),15-pimaradien-3 $\beta$-ol & $\mathrm{nc}$ & nd & 5.45 & 12.80 & 4.46 & 4.40 & 1.39 \\
\hline DITERPENES & & 0.0 & 10.33 & 27.8 & 13.13 & 10.30 & 3.02 \\
\hline TOTAL & & 61.51 & 53.68 & 87.39 & 92.17 & 87.73 & 93.0 \\
\hline
\end{tabular}

TABLE II

Relative percentage of identified compounds of EOs from the vegetative organs of Aldama robusta E.E.Schill. \& Panero in the flowering (leaf, stem, root, and xylopodium) and dormant (root and xylopodium) stages. AI $=$ Arithmetic Index, $n c=$ not calculated, $t=$ traces, $n d=$ not determined. Exclusive compounds are highlighted in the table.

\begin{tabular}{|c|c|c|c|c|c|c|c|}
\hline \multicolumn{4}{|c|}{ Phenological phase } & \multicolumn{2}{|c|}{ Flowering } & \multicolumn{2}{|c|}{ Dormant } \\
\hline & & Leaf & Stem & Xylopodim & Root & Xylopodium & Root \\
\hline Yield $(\% \mathrm{~m} / \mathrm{m})$ & & 0.21 & 0.02 & 0.08 & 0.32 & 0.13 & 0.32 \\
\hline Compound & $\mathbf{A} \mathbf{I}_{\text {(calculated) }}$ & \multicolumn{6}{|c|}{ Relative area (\%) } \\
\hline$\alpha$-pinene & 936 & 9.02 & 19.64 & 39.03 & 31.57 & 65.90 & 69.00 \\
\hline Camphene & 947 & 2.03 & 1.12 & 1.28 & 2.24 & 2.10 & 2.80 \\
\hline Sabinene & 972 & 1.95 & 3.01 & 0.70 & 0.60 & 1.00 & 1.00 \\
\hline$\beta$-pinene & 976 & 9.82 & 11.59 & 0.83 & 0.87 & 1.00 & 1.10 \\
\hline$\beta$-myrcene & 991 & 4.05 & 11.26 & 0.64 & 1.09 & nd & nd \\
\hline$\alpha$-phellandrene & 1007 & $\mathbf{t}$ & 0.38 & 10.11 & 23.10 & 3.10 & 4.80 \\
\hline$\delta$-3-carene & 1012 & nd & nd & 1.16 & 3.91 & 3.50 & 7.60 \\
\hline p-cymene & 1025 & $\mathbf{t}$ & 0.51 & 3.72 & 5.31 & nd & nd \\
\hline Limonene & 1028 & 11.16 & 15.84 & 0.71 & 0.78 & nd & nd \\
\hline Trans- $\beta$-ocimene & 1047 & 7.92 & 2.96 & nd & nd & nd & nd \\
\hline Bornyl acetate & 1284 & 1.88 & 1.51 & 1.50 & 3.62 & 2.00 & 2.89 \\
\hline MONOTERPENES & & 47.83 & 67.82 & 59.68 & 73.09 & 78.6 & 89.19 \\
\hline$\alpha$-copaene & 1373 & $\mathbf{t}$ & 0.44 & 2.81 & 1.92 & 1.60 & t \\
\hline Cyperene & 1397 & $\mathrm{t}$ & $\mathrm{t}$ & 3.19 & 11.66 & 3.10 & 7.79 \\
\hline E-caryophyllene & 1415 & 4.52 & 0.79 & $\mathrm{t}$ & $\mathrm{t}$ & $\mathrm{t}$ & $\mathrm{t}$ \\
\hline
\end{tabular}


TABLE II (continuation)

\begin{tabular}{|c|c|c|c|c|c|c|c|}
\hline \multicolumn{4}{|c|}{ Phenological phase } & \multicolumn{2}{|c|}{ Flowering } & \multicolumn{2}{|c|}{ Dormant } \\
\hline$\gamma$-gurjunene & 1471 & $\mathbf{t}$ & $\mathbf{t}$ & 1.13 & 2.72 & nd & nd \\
\hline Germacrene D & 1480 & 11.98 & 7.56 & 10.41 & 3.54 & 11.30 & 3.0 \\
\hline Bicyclogermacrene & 1495 & 12.52 & 4.97 & $\mathbf{t}$ & $\mathbf{t}$ & nd & nd \\
\hline Spathulenol & 1575 & 3.29 & 3.08 & 0.89 & $\mathrm{t}$ & nd & nd \\
\hline SESQUITERPENES & & 32.31 & 16.84 & 18.43 & 19.84 & 16.00 & 16.00 \\
\hline Manool & nc & $\mathbf{t}$ & $\mathbf{t}$ & 2.67 & 0.56 & 2.1 & nd \\
\hline Ent-8(14),15-pimaradien-3 $\beta$-ol & nc & $\mathrm{t}$ & 0.67 & 2.26 & nd & nd & nd \\
\hline DITERPENES & & 1.49 & 3.53 & 7.19 & 1.15 & 2.1 & 0.0 \\
\hline TOTAL & & 81.63 & 88.19 & 85.30 & 94.08 & 96.7 & 99.98 \\
\hline
\end{tabular}

\section{DISCUSSION}

There were differences in both the yield and chemical composition of EOs from different organs of Aldama arenaria and A. robusta. In A. arenaria, the leaves had the highest levels of EOs, whereas the highest levels of EOs in A. robusta were found in the roots. When compared to other Aldama species (Bombo et al. 2012, 2014) the EOs yield from leaves and stems were lower, while the yield from xylopodia and roots were similar in values. Furthermore, in A. arenaria, the roots and xylopodia had higher levels of EOs during the dormant stage, whereas in A. robusta, only the xylopodia had higher levels of EOs during the dormant stage. Differences in the yield and chemical composition were also observed for EOs from leaves and aerial and underground stems of Senecio crassiflorus var. crassiflorus (Asteraceae) (Murari et al. 2008). Such differences are common and several aspects can influence the production and composition of secondary metabolites in plants, such as physiological variations, environmental conditions, geographic variation, genetic factors (Gershenzon et al. 2000, Figueiredo et al. 2008).

Differences between flowering and dormant stages in chemical composition of EOs were also observed for underground organs of both species. The monoterpenes levels in the roots and xylopodia increased during the dormant stage, whereas the levels of sesqui and diterpenes decreased.
Monoterpenes have been shown to protect against herbivores and pathogens (Bakkali et al. 2008). However, even in the absence of herbivores, some plants show seasonal increases in the concentrations of defence compounds, which must provide a selective advantage over those species that only increase the concentration of monoterpenes after an attack (Lerdau et al. 1994). Thus, the increase in monoterpenes in EOs during the dormant stage of the species studied herein may be interpreted as a chemical defence mechanism in a plant that not only survives in conditions unfavorable to growth but also has only an underground system to maintain itself until the next growth stage (Bombo et al. 2014).

Essential oils from the underground organs of Aldama arenaria and A. robusta were rich in monoterpenes during the flowering stage. The same was observed in A. linearifolia, A. filifolia and A. trichophylla, which presented more than $80 \%$ of the EO composition constituted by monoterpenes in the underground organs (Bombo et al. 2014).

High amounts of sesquiterpenes were also found in A. arenaria and A. robusta, mainly in the EOs from the leaves. According to Loomis and Croteau (1973), sesquiterpenes are metabolically active during plant growth. Thus, individuals from Aldama arenaria and A. robusta would be expected to invest more in the biosynthesis of sesquiterpenes during the flowering stage, when the aerial structures are sprouting. 
Several biological activities were attributed to some of the compounds described here for both studied species. Canales et al. (2008) attributed the antimicrobial activity of the EO from the aerial organs of Viguiera dentata to the presence of compounds such as limonene, bornyl acetate, and spathulenol. These three compounds were also present in the EOs from Aldama robusta, while just bornyl acetate was not detected in $A$. arenaria; moreover limonene was one of the major compounds in the EOs from the aerial organs in both species. Studies with Varronia curassavica (Jacq.) (=Cordia verbenacea DC) (Boraginaceae) have demonstrated anti-inflammatory properties of (-)-trans-caryophyllene and $\alpha$-humulene (Fernandes et al. 2007, Passos et al. 2007). The $\alpha$-humulene may also possess cytotoxic and insecticide activities (Murari et al. 2008). Furthermore, $\alpha$-pinene, $\beta$-pinene, and $\delta$-3-carene, which were present in flowering and dormant stages for both species, have been indicated in phytochemical studies as possessing antimicrobial activity (Lorenzetti et al. 1991, Leite et al. 2007).

Some diterpenes were identified for both species through comparative analysis of their mass spectra with literature data (Adams 2007), mainly for Aldama arenaria. In this species, these compounds belong to the pimaranes class, as previously reported for dichloromethane extracts from the tuberous roots of $A$. arenaria (=Viguiera arenaria) (Ambrosio et al. 2006). An antiproliferative activity has been also associated to the presence of these compounds in chloroform extracts (Oliveira 2013). In $A$. robusta, the diterpenes manoyl oxide and manool, which belong to the labdanes class, were identified in the present study. Previous studies have identified heliangolides (Da Costa et al. 2001) and diterpenes derived from kauranes (Da Costa et al. 1996) in Aldama robusta (=Viguiera robusta).

There are unique compounds in Aldama arenaria and $A$. robusta that may help to distinguish these two species. Fourteen compounds were unique to $A$. arenaria and among them, the sesquiterpene carotol, which exhibits antifungal activity (JasickaMisiaka et al. 2004). For A. robusta, ten compounds were exclusive, and germacrene $\mathrm{D}$, one of the major sesquiterpenes in the EOs from this species, exhibits antimicrobial activity (Murari et al. 2008). Exclusive compounds, as presented here for $A$. arenaria and $A$. robusta, along with the common compounds to each species, provide a characteristic chemical profile that can help in solving taxonomic problems among Aldama species (Bombo et al. 2012, 2014).

This study characterized the yield and essential oil composition of two native Brazilian Aldama species that have been pointed out as having medicinal potential (Arakawa et al. 2008, Nicolete et al. 2009, Carvalho et al. 2011). It was possible to identify some compounds of interest in the pharmaceutical context. Moreover, the comparison between flowering and dormant stages can indicate the best phenological phase to obtain the essential oils considering the target compound in future studies.

\section{ACKNOWLEDGMENTS}

We thank the Conselho Nacional de Desenvolvimento Científico e Tecnológico (CNPq) for grants (Proc. $n^{\circ}$ 303715/2014-6) and the Fundação de Amparo à Pesquisa do Estado de São Paulo (FAPESP) for providing financial support and grants for the first author (Thematic Project Proc. $n^{\circ}$ 2010/514543 and Proc. $n^{\circ}$ 2010/02005-1). We would furthermore like to thank the coordinators of the Estação Ecológica de Itirapina and Mogi Guaçu Biological Reserve (Campininha Farm), SP, Brazil for granting permission to collect plant material for this study.

\section{RESUMO}

Aldama arenaria e $A$. robusta são espécies aromáticas morfologicamente semelhantes e que apresentam 
desenvolvimento sazonal. O rendimento e a composição química dos óleos essenciais dos órgãos vegetativos aéreos e subterrâneos dessas espécies foram caracterizados e comparados, a fim de verificar a produção dos metabólitos voláteis nas fases de floração e dormência e, ainda, para tentar identificar compostos exclusivos para cada espécie. O composto majoritário no óleo essencial das folhas de $A$. arenaria foi o palustrol $(16,22 \%)$ e para os caules aéreos o limoneno $(15,3 \%)$, enquanto que limoneno $(11,16 \%)$ e $\alpha$-pineno $(19,64 \%)$ foram os majoritários para o óleo das folhas e caules aéreos de $A$. robusta, respectivamente. O composto majoritário nos óleos essenciais do sistema subterrâneos foi $\alpha$-pineno em ambas as espécies e fases fenológicas. Grandes quantidades de diterpenos foram encontradas especialmente nos óleos essenciais de $A$. arenaria. Diversos compostos foram únicos para cada uma das espécies analisadas. Este estudo caracterizou o rendimento e a composição química do óleo essencial de $A$. arenaria e $A$. robusta, espécies que possuem potencial medicinal. A comparação entre as fases de floração e dormência pode indicar a melhor época para obter os óleos essenciais, considerando o composto alvo em futuros estudos farmacológicos. Além disso, alguns dos compostos identificados foram exclusivos para cada uma delas, fornecendo um perfil químico único para cada espécie, o que pode ajudar na solução de problemas taxonômicos.

Palavras-chave: Aldama arenaria, Aldama robusta, Viguiera, fases fenológicas, terpenos, órgãos vegetativos.

\section{REFERENCES}

ADAMS RP. 2007. Identification of Essential Oil Components by Gas Chromatography/Mass Spectrometry. Illinois: Allured Publishing Corporation, Carol Stream, 804 p.

Ambrosio S, Arakawa N, Esperandim V, DE ALBUQUERQUE S AND DA COSTA F. 2008. Trypanocidal Activity of Pimarane Diterpenes from Viguiera arenaria (Asteraceae). Phytother Res 22: 1413-1415.

Ambrosio S, Tirapelli C, DA Costa F AND DE OLIVEIRA A. 2006. Kaurane and pimarane-type diterpenes from the Viguiera species inhibit vascular smooth muscle contractility. Life Sci 79: 925-933.

ARAKAWA N, SCHORR K, AMBrosio S, MERForT I AND DA COSTA F. 2008. Further sesquiterpene lactones from Viguiera robusta and the potential anti-inflammatory activity of a heliangolide: Inhibition of human neutrophil elastase release. Z Naturforsch C 63: 533-538.
ARIMURA G, SHIOJIRI K AND KARBAN R. 2010. Acquired immunity to herbivory and allelopathy caused by airborne plant emissions. Phytochemistry 71: 1642-1649.

BAKKALI F, AVERBECK S, AVERBECK D AND WAOMAR M. 2008. Biological effects of essential oils - A review. Food Chem Toxicol 46: 446-475.

Bombo AB, De Oliveira T, DE Oliveira A, REHDER V, MAgentA M AND APPEZZATO-DA-GlóRIA B. 2012. Anatomy and essential oils from aerial organs in three species of Aldama (Asteraceae-Heliantheae) that have a difficult delimitation. Aust J of Bot 60: 632-642.

BOMBO AB, OLIVEIRA TS, OLIVEIRA ASS, REHDER VLG AND APPEZZATO-DA-GLÓRIA B. 2014. Anatomy and essential oil composition of the underground systems of three species of Aldama La Llave (Asteraceae). J Torrey Bot Soc 141(2): 115-125.

CAnales M, Hernandez T, RodrigueZ-MONRoy MA, JimeneZ-Estrada M, Flores CM, Hernadez LB, GiJON IC, QUiROZ S, GARCIA AM AND AVILA G. 2008. Antimicrobial Activity of the Extracts and Essential Oil of Viguiera dentata. Pharm Biol 46: 719-723.

CARVAlho T ET AL. 2011. Antimicrobial Activity of Diterpenes from Viguiera arenaria against Endodontic Bacteria. Molecules 16: 543-551.

Chauveau O ET AL. 2011. Evolution of oil-producing trichomes in Sisyrinchium (Iridaceae): insights from the first comprehensive phylogenetic analysis of the genus. Ann Bot 107: 1287-1312.

Croteau RB, Davis E, Ringer KL AND WiLdung MR. 2005. (-)-Menthol biosynthesis and molecular genetics. Naturwissenschaften 92: 562-577.

DA COSTA F, SCHORR K, ARAKAWA N, SCHILLING E AND SPRING O. 2001. Infraspecific variation in the chemistry of glandular trichomes of two Brazilian Viguiera species (Heliantheae; Asteraceae). J Brazil Chem Soc 12: 403-407.

DA Costa FB, Vichnewski W AND Herz W. 1996. Constituents of Viguiera aspillioides and $V$. robusta. Biochem Syst Ecol 24: 585-587.

DESCHAMPS C, ZANATTA J, BizZO H, OliVEIRA M AND ROSWALKA L. 2008. Seasonal evaluation of essential oil yield of mint species. Cienc Agrotec 32: 725-730.

FAHN A. 1979. Secretory tissue in plants. London: Academic Press, $302 \mathrm{p}$.

FAHN A. 2000. Structure and function of secretory cells. Adv Bot Res 31: 37-75.

FERnandes ES, Passos GF, Medeiros R, CUnha FM, FERREIRA J, CAMPos MM, PIANOWSKI LF AND CALIXTO JB. 2007. Anti-inflammatory effects of compounds alpha-humulene and (-)-trans-caryophyllene isolated from the essential oil of Cordia verbenacea. Eur J Pharmacol 569: 228-236.

Figueiredo AC, BARroso JG, PEDRo LG AND SCHEFFER JJC. 2008. Factors affecting secondary metabolite 
production in plants volatile components and essential oils. Flavour Frag J 23(4): 213-226.

Gershenzon J, MCCONKEY M AND CROTEAU R. 2000. Regulation of monoterpene accumulation in leaves of peppermint. Plant Physiol 122: 205-213.

GöREN A, TOPÇU G, BILSEL G, BILSEL M, AYDOĞMUş Z AND PEZZUTO JM. 2002. The chemical constituents and biological activity of essential oil of Lavandula stoechas ssp. stoechas. Z Naturforsch C 57: 797-800.

HARBorne JB AND TURner BL. 1984. Plant Chemosystematics. London: Academic Press.

Hipolito U, Rodrigues G, LUNARdi C, BONAVENTURA D, Ambrosio S, De Oliveira A, Bendhack L, DA Costa F AND TIRAPELli C. 2009. Mechanisms underlying the vasorelaxant action of the pimarane ent8(14),15-pimaradien-3 beta-ol in the isolated rat aorta. Eur J Pharmacol 616: 183-191.

JASICKA-MISIAKA JL, NOWAKOWSKA EM, WIECZOREK PP, MŁYNARZ P AND KAFARSKI P. 2004. Antifungal activity of the carrot seed oil and its major sesquiterpene compounds. Z Naturforsch 59: 791-796.

LEITE AM, LimA EO, SOUZA EL, Diniz MFFM, TRAJANO VN AND MEDEIROS IA. 2007. Inhibitory effect of $\beta$-pinene, $\alpha$-pinene and eugenol on the growth of potential infectious endocarditis causing Gram-positive bacteria. Rev Bras Cienc Farm 43: 121-126.

LERDAU M, LiTVAK M AND MONSON R. 1994. Plant chemical defense: monoterpenes and the growth-differentiation balance hypothesis. Tree 9: 58-61.

LOOMIS WD AND CROTEAU RB. 1973. Biochemistry and physiology of lower terpenoids. In: Runeckles VC and Mabry TJ (Eds), Terpenoids: structure biogenesis and distribution New York, Academic Press, p. 147-186.

LorenzetTi BB, SouzA GE, SARTI SJ, SANTOS FILHO D AND FERREIRA SH. 1991. Myrcene mimics the peripheral analgesic activity of lemongrass tea. J Ethnopharmacol 34: 43-48.

MAGEnTA MAG. 2006. Viguiera Kunth (Asteraceae, Heliantheae) na América do Sul e sistemática das espécies do Brasil. PhD thesis, Universidade de São Paulo, São Paulo, $366 \mathrm{p}$.

MAGENTA MAG AND PIRANI JR. 2014. Novidades taxonômicas em Aldama (Asteraceae-Heliantheae). Rodriguésia 65: 175-192.

Magenta MAG, Pirani JR And Mondin CA. 2010. Novos táxons e combinações em Viguiera (AsteraceaeHeliantheae). Rodriguésia 61: 1-11.

Marotti M, PicCAGlia R AND Giovanelli E. 1996. Differences in essential oil composition of basil (Ocimum basilicum L.) Italian cultivars related to morfological characteristics. J Agr Food Chem 44: 3926-3929.
Murari A, De CARVAlho F, HeinzMann B, Michelot T, Horner R AND Mallmann C. 2008. Composition and antibacterial activity of the essential oils of Senecio crassiflorus var. crassiflorus. Quim Nova 31: 1081-1084.

Nicolete R, ARAKaWA N, RiUs C, Nomizo A, Jose P, DA Costa F, SAnz M AND FACCIOLI L. 2009. Budlein A from Viguiera robusta inhibits leukocyte-endothelial cell interactions, adhesion molecule expression and inflammatory mediators release. Phytomedicine 16: 904-915.

OLIVEIRA ASS. 2013. Estudo da composição química e avaliação da atividade antiproliferativa in vitro de Aldama arenaria Baker (Sin.: Viguiera arenaria). MsC dissertation, Universidade Estadual de Campinas, Campinas, 116 p. (Unpublished).

Passos GF, FERnAndes ES, CUnha FM, FERreira J, Pianowski LF, CAMpos MM And CALiXto JB. 2007. Anti-inflammatory and anti-allergic properties of the essential oil and active compounds from Cordia verbenacea. J Ethnopharmacol 110: 323-333.

Porto T, Furtado N, Heleno V, Martins C, DA Costa F, SEVEriano M, Silva A, Veneziani R AND AMBRosio S. 2009. Antimicrobial ent-pimarane diterpenes from Viguiera arenaria against Gram-positive bacteria. Fitoterapia 80: 432-436.

RYAN CA. 2001. Plant biology: night moves of pregnant moths. Nature 410: 530-531.

SANGWAN NS, FAROOQI AHA, SHABIH F AND SANGWAN RS. 2001. Regulation of essential oil production in plants. Plant Growth Regul 34: 3-21.

SIMÕES CMO AND SPITZER V. 2004. Óleos voláteis. In: Simões CMO et al. (Eds), Farmacognosia: da planta ao medicamento, $6^{\text {a }}$ ed., Porto Alegre: UFRGS, p. 467-495.

TIRAPELLI C, AMBRosio S, DA COSTA F AND DE OLIVEIRA A. 2002. Inhibitory action of kaurenoic acid from Viguiera robusta (Asteraceae) on phenylephrine-induced rat carotid contraction. Fitoterapia 73: 56-62.

VALERIO D, CUNHA T, ARAKAWA N, LEMOS H, DA COSTA F, PARAdA C, FERreira S, CUnha F AND VERri W. 2007. Anti-inflammatory and analgesic effects of the sesquiterpene lactone budlein A in mice: Inhibition of cytokine production-dependent mechanism. Eur J Pharmacol 562: 155-163.

WINK M. 2009. Annual plant reviews: biochemistry of plant secondary metabolism. New York, Wiley-Blackwell, n. $40,2^{\text {nd }}$ ed., 464 p.

\section{SUPPLEMENTARY MATERIAL}

\section{Mass Spectra of Diterpenes}


